\title{
MULTIDRUG RESISTANCE IN CANCER: ROLE OF ATP-DEPENDENT TRANSPORTERS
}

\author{
Michael M. Gottesman, Tito Fojo and Susan E. Bates \\ Chemotherapeutics are the most effective treatment for metastatic tumours. However, the ability \\ of cancer cells to become simultaneously resistant to different drugs - a trait known as \\ multidrug resistance - remains a significant impediment to successful chemotherapy. Three \\ decades of multidrug-resistance research have identified a myriad of ways in which cancer cells \\ can elude chemotherapy, and it has become apparent that resistance exists against every \\ effective drug, even our newest agents. Therefore, the ability to predict and circumvent drug \\ resistance is likely to improve chemotherapy.
}

Patients who have cancer that does not respond to local excision or radiation (about $50 \%$ of total cancer cases), and patients with haematological malignancies, are treated with chemotherapy, immunotherapy and biological-response modifiers. But why can some patients be cured by these approaches and others respond transiently or incompletely? Host and tumour genetic alterations, epigenetic changes and tumour environment all seem to contribute to the complex story of cancer drug resistance ${ }^{1}$.

\section{Cellular mechanisms of multidrug resistance}

There are two general classes of resistance to anticancer drugs: those that impair delivery of anticancer drugs to tumour cells, and those that arise in the cancer cell itself due to genetic and epigenetic alterations that affect drug sensitivity. Impaired drug delivery can result from poor absorption of orally administered drugs, increased drug metabolism or increased excretion, resulting in lower levels of drug in the blood and reduced diffusion of drugs from the blood into the tumour mass ${ }^{2,3}$. Recent studies have emphasized the importance of the tumour vasculature and an appropriate pressure gradient for adequate drug delivery to the tumour ${ }^{4}$. In addition, some cancer cells that are sensitive to chemotherapy as monolayer cells in culture become resistant when transplanted into animal models ${ }^{5}$. This indicates that environmental factors, such as the extracellular matrix or tumour geometry, might be involved in drug resistance. Cancer cells grown in culture as three-dimensional spheroids, mimicking their in vivo geometry, have also been shown to become resistant to cancer drugs ${ }^{2,5,6}$. Much remains to be learned about this type of drug resistance and its role in clinical oncology.

Cellular mechanisms of drug resistance have been intensively studied, as experimental models can be easily generated by in vitro selection with cytotoxic agents. Cancer cells in culture can become resistant to a single drug, or a class of drugs with a similar mechanism of action, by altering the drug's cellular target or by increasing repair of drug-induced damage, frequently to DNA. After selection for resistance to a single drug, cells might also show cross-resistance to other structurally and mechanistically unrelated drugs - a phenomenon that is known as MULTIDRUG RESISTANCE. This might explain why treatment regimens that combine multiple agents with different targets are not more effective.

As illustrated in FIG. 1, different types of cellular multidrug resistance have been described. Resistance to natural-product hydrophobic drugs - sometimes known as classical multidrug resistance - generally results from expression of ATP-dependent efflux pumps with broad drug specificity. These pumps belong to a 


\section{Summary}

- Multidrug resistance of cancer cells is a potentially surmountable obstacle to effective chemotherapy of cancer.

- ATP-binding cassette (ABC) transporters, including MDR1 (ABCB1), MRP1 (ABCC1) and $A B C G 2$, can confer multidrug resistance to cancer cells in vitro.

- MRP2 (ABCC2), MRP3 (ABCC3), MRP4 (ABCC4), MRP5 (ABCC5), ABCA2 and BSEP (ABCB11) are capable of transporting drugs; future studies are needed to determine a role in drug resistance.

- ABC transporters such as MDR1 and MRP1 are expressed in many human cancers, including leukaemias and some solid tumours; in some studies, expression of these transporters has been shown to correlate with response to therapy and survival

- Inhibitors of $\mathrm{ABC}$ transporters such as MDR1/P-glycoprotein have been tested in clinical trials with a suggestion of benefit, especially in acute myelogenous leukaemia.

- Interpretation of clinical trials using inhibitors of MDR1/P-glycoprotein has been confounded by their effects on the pharmacokinetics of anticancer drugs.

- Development of inhibitors of $A B C$ transporters should focus on potency and specificity to minimize unexpected pharmacokinetic effects.

- Efficacy should be confirmed using surrogate assays.

- Normal tissues might be protected from toxicity by gene transfer of drug-resistance genes.

- Prevention of $\mathrm{ABC}$ transporter induction in cancer cells might help to avert drug resistance.
MULTIDRUG RESISTANCE Simultaneous resistance to several structurally unrelated drugs that do not have a common mechanism of action.

VINCA ALKALOIDS A family of natural-product anticancer drugs, extracted from the periwinkle family, that depolymerize microtubules. Examples include vincristine and vinblastine.

ANTHRACYCLINES Semi-synthetic anticancer derivatives of anthraquinone that intercalate into DNA and inhibit DNA topoisomerase II. Examples include daunorubicin and doxorubicin.

CYTOCHROME P450 A group of enzymes that are located on the endoplasmic reticulum, and are involved in drug metabolism and detoxification. They are primarily expressed in the liver and small intestine.

MULTIFACTORIAL MULTIDRUG RESISTANCE

Multidrug resistance caused by several different mechanisms of resistance that operate simultaneously. family of ATP-binding cassette $(\mathrm{ABC})$ transporters that share sequence and structural homology. So far, 48 human $\mathrm{ABC}$ genes have been identified and divided into seven distinct subfamilies (ABCA-ABCG) on the basis of their sequence homology and domain organization $^{7}$. Resistance results because increased drug efflux lowers intracellular drug concentrations. Drugs that are affected by classical multidrug resistance include the VINCA ALKALOIDS (vinblastine and vincristine), the ANTHRACYCLINES (doxorubicin and daunorubicin), the RNA transcription inhibitor actinomycin-D and the microtubule-stabilizing drug paclitaxe ${ }^{8}$.

Resistance can also be mediated by reduced drug uptake. Water-soluble drugs that 'piggyback' on transporters and carriers that are used to bring nutrients into the cell, or agents that enter by means of endocytosis, might fail to accumulate without evidence of increased efflux. Examples include the antifolate methotrexate, nucleotide analogues, such as 5-fluorouracil and 8 -azaguanine, and cisplatin ${ }^{9,10}$.

Multidrug resistance can also result from activation of coordinately regulated detoxifying systems, such as DNA repair and the сүтоснRоме P450 mixedfunction oxidases. Indeed, coordinate induction of the multidrug transporter P-glycoprotein (PGP) and cytochrome $\mathrm{P} 4503 \mathrm{~A}$ has been observed ${ }^{11}$. This type of multidrug resistance can be induced after exposure to any drug. Recent evidence indicates that certain orphan nuclear receptors, such as SXR, might be involved in mediating this global response to environmental stress ${ }^{12}$.

Finally, resistance can result from defective apoptotic pathways. This might occur as a result of malignant transformation; for example, in cancers with mutant or non-functional p53 (REF. 158). Alternatively, cells might acquire changes in apoptotic pathways during exposure to chemotherapy, such as alteration of ceramide levels ${ }^{13}$ or changes in cell-cycle machinery, which activate checkpoints and prevent initiation of apoptosis.

An important principle in multidrug resistance is that cancer cells are genetically heterogeneous. Although the process that results in uncontrolled cell growth in cancer favours clonal expansion, tumour cells that are exposed to chemotherapeutic agents will be selected for their ability to survive and grow in the presence of cytotoxic drugs. These cancer cells are likely to be genetically heterogeneous because of the mutator phenotype. So, in any population of cancer cells that is exposed to chemotherapy, more than one mechanism of multidrug resistance can be present. This phenomenon has been called MULTIFACTORIAL MULTIDRUG RESISTANCE.

\section{ATP-dependent transporters}

Selection of cancer cells in culture with natural-product anticancer drugs, such as paclitaxel, doxorubicin, or vinblastine, frequently results in multidrug resistance that is due to expression of the $\mathrm{ABC}$ transporter PGP, the product of the $A B C B 1$ (or MDR1) gene ${ }^{14,15}$. PGP is a broad-spectrum multidrug efflux pump that has 12 transmembrane regions and two ATP-binding sites $^{16}$ (FIG. 2). The transmembrane regions bind hydrophobic drug substrates that are either neutral or positively charged, and are probably presented to the transporter directly from the lipid bilayer ${ }^{8}$. Two ATP hydrolysis events, which do not occur simultaneously, are needed to transport one drug molecule ${ }^{17}$. Binding

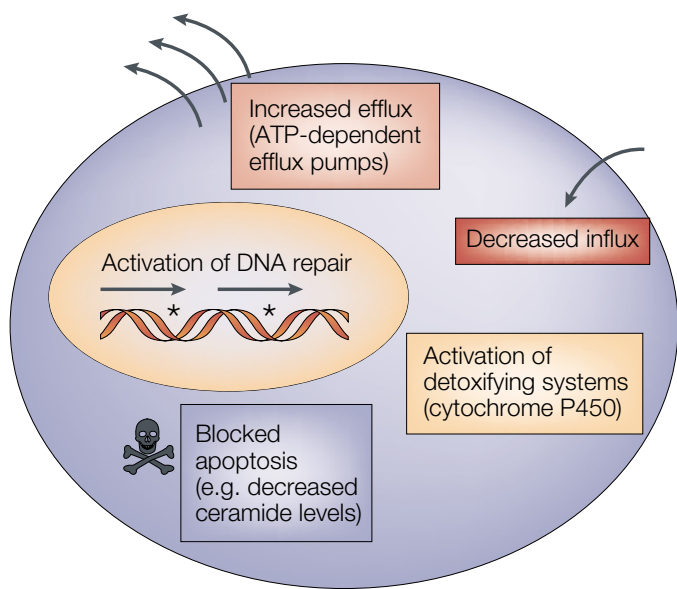

Figure 1 | Cellular factors that cause drug resistance. Cancer cells become resistant to anticancer drugs by several mechanisms. One way is to pump drugs out of cells by increasing the activity of efflux pumps, such as ATP-dependent transporters. Alternatively, resistance can occur as a result of reduced drug influx - a mechanism reported for agents that 'piggyback' on intracellular carriers or enter the cell by means of endocytosis. In cases in which drug accumulation is unchanged, activation of detoxifying proteins, such as cytochrome P450 mixed-function oxidases, can promote drug resistance. Cells can also activate mechanisms that repair drug-induced DNA damage. Finally, disruptions in apoptotic signalling pathways (e.g. p53 or ceramide) allow cells to become resistant to drug-induced cell death. 
Structure

a

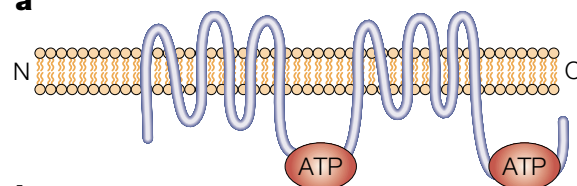

b

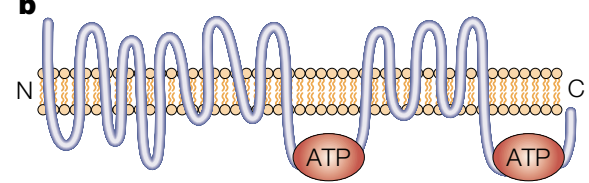

c

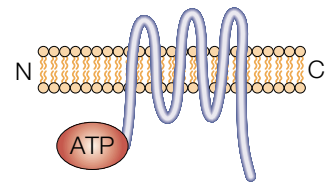

Figure 2 | Structures of ABC transporters known to confer drug resistance. The structures of three categories of $A B C$ transporter. $\mathbf{a} \mid A B C$ transporters such as multidrug resistance MDR1 and multidrug-resistance-associated protein $4 \mathrm{MRP} 4$ have 12 transmembrane domains and two ATPbinding sites. $\mathbf{b} \mid$ The structures of MRP1, 2, 3 and 6 are similar in that they possess two ATPbinding regions. They also contain an additional domain that is composed of five transmembrane segments at the amino-terminal end, giving them a total of 17 transmembrane domains. c | The 'half-transporter' ABCG2 contains six transmembrane domains and one ATP-binding region - in this case, on the amino-terminal side $(\mathrm{N})$ of the transmembrane domain. In other 'half-transporters', such as the transporter associated with antigen processing (TAP), the ATP-binding cassette is found on the carboxy-terminal $(\mathrm{C})$ side of the transmembrane domain. Half-transporters are thought to homodimerize or heterodimerize to function.

FLIPPASE

A transport system that moves substrates from one leaflet of the membrane bilayer to the other leaflet. of substrate to the transmembrane regions stimulates the ATPase activity of PGP, causing a conformational change that releases substrate to either the outer leaflet of the membrane (from which it can diffuse into the medium) or the extracellular space ${ }^{18}$. Hydrolysis at the second ATP site seems to be required to 're-set' the transporter so that it can bind substrate again, completing one catalytic cycle ${ }^{19}$.

PGP efficiently removes cytotoxic drugs and many commonly used pharmaceuticals from the lipid bilayer. Its broad substrate specificity presumably reflects a large, polymorphous drug-binding domain or domains within the transmembrane segments. Because PGP binds many different hydrophobic compounds, it has been easy to find potent PGP inhibitors. Two inhibitors that are used in the laboratory and in clinical trials that attempted to reverse drug resistance are the calcium channel blocker verapamil and the immunosuppressant cyclosporin $A$.

As not all multidrug-resistant cells express PGP, a search for other efflux pumps was initiated, leading to the discovery of the multidrug-resistance-associated protein 1 (MRP1, or ABCC1) ${ }^{20}$. MRP1 is similar to PGP in structure, with the exception of an aminoterminal extension that contains five-membranespanning domains attached to a PGP-like core (FIG. 2). MRP1 recognizes neutral and anionic hydrophobic natural products, and transports glutathione and other conjugates of these drugs, or, in some cases - such as for vincristine - co-transports unconjugated glutathione $\mathrm{e}^{21-23}$. The discovery of MRP1 stimulated a genomic search for homologues, leading to the discovery of eight additional members of the ABCC subfamily of transporters, of which six have been studied in some detail $^{24}$. Like MRP1, some of these MRPs have the fivetransmembrane amino-terminal extension (ABCC2, ABCC3 and ABCC6, also named MRP2, 3, and 6), whereas others do not. Many MRP family members transport drugs in model systems and therefore have the potential to confer drug resistance ${ }^{24}$.

Some anticancer drugs, such as mitoxantrone, are poor substrates for MDR1 and MRP1. Selection for mitoxantrone resistance results in multidrug-resistant cells that produce a more distant member of the $\mathrm{ABC}$ transporter family, ABCG2 - also known as MXR (mitoxantrone-resistance gene), BCRP (breast cancer resistance protein) or $\mathrm{ABC}-\mathrm{P}$ ( $\mathrm{ABC}$ transporter in placenta ${ }^{25-27}$. This transporter is thought to be a homodimer of two half-transporters, each containing an ATP-binding domain at the amino-terminal end of the molecule and six transmembrane segments (FIG. 2). The first two original ABCG2 genes that were cloned from resistant cells encoded proteins with either a threonine or glycine substituted for arginine at amino acid 482 , giving them much broader substrate specificity, including the ability to transport doxorubicin ${ }^{28,29}$. This finding, together with many well-documented mutations in PGP, shows that even single amino-acid substitutions can change substrate specificity ${ }^{8}$.

Other ABC family members have been associated with drug resistance. For example, the bile salt export protein (BSEP, also known as ABCB11), first reported as the 'sister of PGP' (SPGP), is expressed at high levels in liver cells, and in transfection experiments it confers lowlevel resistance to paclitaxel ${ }^{30}$. MDR3 (sometimes called MDR2), a phosphatidylcholine FLIPPASE that is closely related to PGP, normally transports phospholipids into bile, but can transport paclitaxel and vinblastine, albeit inefficiently unless it is mutated ${ }^{31-33}$. Finally, $A B C A 2$ is overexpressed in estramustine-resistant cells $\mathrm{s}^{7,34,35}$. Estramustine is a nitrogen mustard derivative of oestradiol, so $A B C A 2$ - which is expressed intracellularly in endosomal/lysosomal vesicles - might participate in steroid transport.

Although the lung resistance protein (LRP) is not an $\mathrm{ABC}$ transporter, it is frequently included in discussions of drug resistance, as it is expressed at high levels in drug-resistant cell lines and some tumours ${ }^{36}$. LRP is a major vault protein found in the cytoplasm and on the nuclear membrane. Vaults are large ribonucleoprotein particles that are present in all eukaryotic cells. Their shape is reminiscent of the nucleopore central plug, and the major vault proteins account for $70 \%$ of their mass. Although their role in normal physiology is not yet established, vaults might confer drug resistance by redistributing drugs away from intracellular targets.

\section{ABC transporters in normal cells}

Although many $A B C$ transporters have been identified as drug-resistance proteins, they are all expressed in normal tissues ${ }^{33,37-48}$ (TABLE 1). Consistent with their wide distribution, it is becoming clear that in addition to exogenously administered drugs, $\mathrm{ABC}$ proteins transport numerous endogenous substrates. 


\begin{tabular}{|c|c|c|c|c|c|c|}
\hline Common Name & Systematic name & Tissue & $\begin{array}{l}\text { Non-chemotherapy } \\
\text { substrates }\end{array}$ & $\begin{array}{l}\text { Chemotherapy } \\
\text { substrates } \\
\text { (known and suspected) }\end{array}$ & $\begin{array}{l}\text { Defects in } \\
\text { human disease }\end{array}$ & References \\
\hline PGP/MDR1 & ABCB1 & $\begin{array}{l}\text { Intestine, } \\
\text { liver, kidney, } \\
\text { placenta, } \\
\text { blood-brain } \\
\text { barrier }\end{array}$ & $\begin{array}{l}\text { Neutral and cationic } \\
\text { organic compounds, } \\
\text { many commonly } \\
\text { used drugs }\end{array}$ & $\begin{array}{l}\text { Doxorubicin, daunorubicin, } \\
\text { vincristine, vinblastine, } \\
\text { actinomycin-D, paclitaxel, } \\
\text { docetaxel, etoposide, } \\
\text { teniposide, bisantrene, } \\
\text { homoharringtonine (STI-571) }\end{array}$ & $\begin{array}{l}\text { None known; } \\
\text { altered sensitivity } \\
\text { to drugs }\end{array}$ & 8 \\
\hline MDR2 & ABCB4 & Liver & $\begin{array}{l}\text { Phosphatidylcholine, } \\
\text { some hydrophobic } \\
\text { drugs }\end{array}$ & Paclitaxel, vinblastine & $\begin{array}{l}\text { Progressive familial } \\
\text { intrahepatic } \\
\text { cholestasis }\end{array}$ & $31,33,66,67$ \\
\hline MRP1 & $\mathrm{ABCC} 1$ & All tissues & $\begin{array}{l}\text { Glutathione and other } \\
\text { conjugates, organic } \\
\text { anions, leukotriene C4 }\end{array}$ & $\begin{array}{l}\text { Doxorubicin, epirubicin, } \\
\text { etoposide, vincristine, } \\
\text { methotrexate }\end{array}$ & None known & $20-24$ \\
\hline $\begin{array}{l}\text { MRP2, } \\
\text { CMOAT }\end{array}$ & ABCC2 & $\begin{array}{l}\text { Liver, kidney, } \\
\text { intestine }\end{array}$ & $\begin{array}{l}\text { Similar to MRP1, non- } \\
\text { bile salt organic anions }\end{array}$ & $\begin{array}{l}\text { Methotrexate, etoposide, } \\
\text { doxorubicin, cisplatin, } \\
\text { vincristine, mitoxantrone }\end{array}$ & $\begin{array}{l}\text { Dubin-Johnson } \\
\text { syndrome }\end{array}$ & $24,60-63$ \\
\hline MRP3 & ABCC3 & $\begin{array}{l}\text { Pancreas, } \\
\text { kidney, } \\
\text { intestine, } \\
\text { liver, adrenal } \\
\text { glands }\end{array}$ & $\begin{array}{l}\text { Glucuronate and } \\
\text { glutathione conjugates, } \\
\text { bile acids }\end{array}$ & $\begin{array}{l}\text { Etoposide, teniposide, } \\
\text { methotrexate, cisplatin, } \\
\text { vincristine, doxorubicin }\end{array}$ & None known & 37,38 \\
\hline MRP4 & $\mathrm{ABCC} 4$ & $\begin{array}{l}\text { Prostate, } \\
\text { testis, ovary, } \\
\text { intestine, } \\
\text { pancreas, } \\
\text { lung }\end{array}$ & $\begin{array}{l}\text { Nucleotide analogues, } \\
\text { organic anions }\end{array}$ & Methotrexate, thiopurines & None known & 39,40 \\
\hline MRP5 & ABCC5 & Most tissues & $\begin{array}{l}\text { Nucleotide analogues, } \\
\text { cyclic nucleotides, } \\
\text { organic anions }\end{array}$ & $\begin{array}{l}\text { 6-Mercaptopurine } \\
\text { 6-Thioguanine }\end{array}$ & None known & 41,42 \\
\hline MRP6 & ABCC6 & Liver, kidney & $\begin{array}{l}\text { Anionic cyclic } \\
\text { pentapeptide }\end{array}$ & Unknown & $\begin{array}{l}\text { Pseudoxanthoma } \\
\text { elasticum (substrate } \\
\text { unknown) }\end{array}$ & $43-46,58$ \\
\hline $\begin{array}{l}\text { MXR, } \\
\text { BCRP, } \\
\text { ABC-P }\end{array}$ & ABCG2 & $\begin{array}{l}\text { Placenta, } \\
\text { intestine, } \\
\text { breast, liver }\end{array}$ & Prazosin & $\begin{array}{l}\text { Doxorubicin, daunorubicin, } \\
\text { mitoxantrone, topotecan, } \\
\text { SN-38 }\end{array}$ & None known & $25-29,54$ \\
\hline $\begin{array}{l}\text { BSEP, } \\
\text { SPGP }\end{array}$ & ABCB11 & Liver & Bile salts & Paclitaxel & $\begin{array}{l}\text { Progressive familial } \\
\text { intrahepatic } \\
\text { cholestasis }\end{array}$ & $\begin{array}{r}30,47,48 \\
64,65\end{array}$ \\
\hline ABCA2 & $\mathrm{ABCA} 2$ & $\begin{array}{l}\text { Brain, } \\
\text { monocytes }\end{array}$ & $\begin{array}{l}\text { Steroid derivatives, } \\
\text { lipids }\end{array}$ & Estramustine & $\begin{array}{l}\text { Intracellular steroid } \\
\text { transport }\end{array}$ & $7,34,35$ \\
\hline
\end{tabular}

BILIRUBIN

A breakdown product of

haemoglobin that is processed

by the liver, where it is

conjugated to glucuronic acid and excreted in the bile.

Accumulation of bilirubin in the

blood and tissues can lead to

jaundice and neurological

damage.
$\mathrm{ABC}$ transporters have an important role in regulating central nervous system permeability. The brain is protected against blood-borne toxins by the bloodbrain barrier (BBB), and the blood-cerebrospinal-fluid (CSF) barrier. The BBB is formed by the endothelial cells of capillaries, with PGP located on the luminal surface, preventing the penetration of cytotoxins across the endothelium ${ }^{49,50}$. MRP proteins such as MRP1 are localized to the basolateral membrane of the choroid plexus, where they serve to pump the metabolic waste products of CSF into the blood ${ }^{51}$. ABC transporters also seem to protect testicular tissue and the developing fetus in a similar manner. In the testis, as in the brain, PGP transports toxins into the capillary lumen. MRP1, on the other hand, is localized on the basolateral surface of Sertoli cells, protecting sperm within the testicular tubules. In the placenta, PGP is localized on the apical syncytiotrophoblast surface, where it can protect the fetus from toxic cationic xenobiotics ${ }^{52}$. MRP family members and the half- transporter ABCG2 are also localized in placenta ${ }^{53,54}$. MRP1 and other isoforms might be involved in protecting fetal blood from toxic organic anions and excreting glutathione/glucuronide metabolites into the maternal circulation ${ }^{55}$.

Whereas $A B C$ transporters are expressed in the brain, testis and placenta to protect these 'sanctuaries' from cytotoxins, the liver, gastrointestinal tract and kidney use them to excrete toxins, protecting the entire organism. PGP is localized in the apical membranes of hepatocytes, where it transports toxins into bile $^{56}$. In humans, MRP3 is localized to the basolateral surface of hepatocytes, where it transports organic anions from liver back into the bloodstream ${ }^{57}$. A similar role might exist for MRP6, which has been found to be expressed at high levels by liver cells ${ }^{58}$. MRP2 (cMOAT) is also localized on the apical surface of hepatocytes, where it transports BILIRUBIN-glucuronide and other organic anions into bile ${ }^{59}$. Mutations that disrupt MRP2 function cause bilirubin accumulation 
and jaundice in rats ${ }^{60,61}$ and in patients with DubinJohnson syndrome ${ }^{62,63}$. Mutations in BSEP are associated with progressive familial intrahepatic cholestasis type-2, which is characterized by reduced secretion of bile salts and hepatic failure ${ }^{64,65}$. Finally, MDR2 functions as a phosphatidylcholine trans-locase, which reduces the toxicity of bile salts ${ }^{66}$. Loss of MDR2 function results in progressive familial intrahepatic cholestasis type-3 (REFS 31,67).

In the gastrointestinal tract, PGP is localized in apical membranes of mucosal cells, where it extrudes toxins, forming a first line of defence. Increased tissue concentrations of PGP substrates in Mdr1a/Mdr1b-knockout mice indicate that PGP might have a significant role in determining oral drug bioavailability. Studies have shown increased tissue absorption of putative PGP substrates following oral administration when a PGP inhibitor is administered concurrently ${ }^{68-70}$. Additionally, PGP actively secretes intravenously administered drugs into the gastrointestinal tract ${ }^{71}$. In contrast to PGP, MRP1 is located in the basolateral membrane of mucosal cells, and therefore transports substrates into the interstitium and the bloodstream, rather than across the apical surface into the intestinal lumen ${ }^{72}$. Consistent with the absence of expression on the apical surface, Mrp1-null mice have not been found to have alterations in drug pharmacokinetics ${ }^{73}$. MRP2, on the other hand, localizes to the CANALICULAR MEMBRANE of hepatocytes and the apical surface of epithelial cells, and has a primary role in the excretion of bilirubin-glucuronide. Studies confirmed that MRP2 was capable of mediating drug efflux, and a recent study showed increased bioavailability of a food-derived carcinogen - 2-amino-1-methyl6-phenylimidazo[4,5- $b$ ] pyridine - in Mrp2-null rats $^{74}$. This indicates that MRP2, like PGP, might also regulate drug bioavailability.

\section{ABC transporters in human cancers}

Although it seems likely that cancer cells use several different types of $A B C$ transporter to gain drug resistance, most clinical studies have focused on PGP. Early studies showed that PGP was highly expressed in colon, kidney, adrenocortical and hepatocellular cancers ${ }^{75,76}$. Initially, there was hope that increases in PGP expression alone could explain cancer drug resistance. However, the failure of these cancers to respond to drugs that are not PGP substrates indicated that other factors are involved, and attention turned to cancers that acquire resistance following chemotherapy. In seeking to define the role of PGP in drug resistance, researchers have assumed that PGP expression is highest in tumours that are dependent on expression for survival, that expression impairs response to chemotherapy, and that expression levels increase as tumours become drug resistant. On the basis of these assumptions, clinical trials aimed at increasing chemotherapy sensitivity in drug-resistant tumours, through inhibition of PGP, have been implemented.

So, does PGP expression confer drug resistance in human cancer? Most studies that correlate PGP expression with clinical outcome have been small, retrospective, single-institution studies with insufficient power to draw reliable conclusions ${ }^{77}$. One problem with designing a study that provides statistically valid results is that methods for detecting PGP expression are imperfect. This is primarily due to the lack of specificity of many commonly used anti-PGP antibodies. To complicate matters, researchers also use different methods to quantify expression, to control for tumour heterogeneity, and to account for the presence of normal tissue in tumour biopsies ${ }^{78}$. Despite efforts to bring uniformity to PGP quantification, it is still difficult to discern valid from invalid data.

Expression of MRP1 has also been analysed in clinical samples. Antibodies against MRP1 seem to be more specific than those that recognize $\mathrm{PGP}^{79}$, and MRP1 is highly expressed in leukaemias, oesophageal carcinoma and non-small-cell lung cancers ${ }^{80}$. Conclusions about expression levels of other $\mathrm{ABC}$ transporters in human tissue await more extensive analysis.

Leukaemia. The most uniform associations between MDR1/PGP expression and drug resistance have been reported in acute myelogenous leukaemia (AML). PGP expression has been reported in leukaemic cells from about one-third of patients with AML at the time of diagnosis, and more than $50 \%$ of patients at relapse; higher levels occur in certain subtypes, including secondary leukaemias ${ }^{81-83}$. PGP expression is correlated with a reduced complete remission rate, and a higher incidence of refractory disease - a surprising finding, as treatment regimens include not only the PGP substrate daunorubicin, but also AraC, which is not a PGP substrate ${ }^{81,84-86}$. Recent studies report that PGP expression is associated with a poorer prognosis, although the magnitude of the effects on response and survival is probably not as great as initially thought. These clinical results are supported by ex vivo studies of leukaemic cells, which have shown that PGP expression reduces the intracellular accumulation of daunorubicin ${ }^{86,87}$. In addition, administration of a PGP inhibitor increases daunorubicin accumulation in leukaemic cells ${ }^{88}$.

MRP1 and LRP expression have also been evaluated in leukaemia. Increased MRP1 expression has been reported in chronic lymphocytic and prolymphocytic leukaemia cells ${ }^{89}$. Expression levels are less frequently elevated in AML cells (10-34\% $)^{81,85,90}$, and these studies lead to different conclusions about whether MRP1 confers a poor prognosis. So far, the largest trial in untreated patients found no correlation between MRP1 or LRP expression and prognosis, but observed a correlation between $P G P$ expression and prognosis ${ }^{81}$. Finally, low expression levels of BCRP/ MXR have been observed in AML cells ${ }^{91}$. Taken together, the clinical data support a role for PGP in drug resistance in AML patients, and for MRP1 expression in chronic lymphocytic and prolymphocytic leukaemias. Additional studies are needed to confirm and extend these findings.

Breast cancer. Detection of transporters in solid tumour samples has been more difficult. A 1997 metaanalysis of 31 reports from 1989-1996 found that 41\%
Surface of the hepatocyte that faces the biliary canaliculus, through which bile is excreted. 
of breast tumours expressed PGP ${ }^{92}$. PGP expression increased after therapy and was associated with a greater likelihood of treatment failure. However, there was considerable interstudy variability - a finding that has persisted in the reports since 1996 (REFS 93,96,97,159-161), preventing a solid conclusion about the role of PGP in breast cancer. Recent imaging studies using ${ }^{99 \mathrm{~m}} \mathrm{Tc}$ (technetium)-sestamibi (Cardiolite), a transport substrate recognized by PGP, indicate that its activity is increased in breast carcinomas ${ }^{93-95}$.

Whether the MRP1 expression levels associated with breast cancer are enough to confer drug resistance is not yet resolved ${ }^{96,97}$. As MRP1 is expressed ubiquitously, it is not surprising that using reverse transcriptase polymerase chain reaction (RT-PCR), MRP1 mRNA can be detected in all breast cancer samples at levels comparable to that in normal tissues. One immunohistochemical analysis of a series of resected invasive primary breast carcinomas reported a correlation between relapse-free survival and MRP1 expression ${ }^{98}$.

Other solid tumours. Variability in expression is also a problem for other solid tumours. In ovarian cancer samples, $16-47 \%$ were found to express PGP, as measured by immunohistochemistry ${ }^{162-164}$. Critical analysis of these data reveals that PGP is expressed by only about $20 \%$ of ovarian cancers when samples were taken at diagnosis. This makes it difficult to demonstrate a correlation between expression and outcomes, such as disease-free survival, particularly given the importance of cisplatin in therapy.

In lung cancer samples, MDR1 mRNA expression was reported to be increased in 15-50\% of tumours ${ }^{99-101}$. The incidence of MRP1 expression is much higher (about $80 \%$ ) in small-cell lung cancer (SCLC) samples. MRP1 expression was detected in $100 \%$ of non-smallcell lung cancers (NSCLC), with higher levels noted in $30 \%$ of the samples - this might not be surprising, given its ubiquitous expression in normal lung tissue ${ }^{101,102}$. Immunohistochemical studies confirmed the predominantly plasma-membrane localization pattern of MRP1 (REF. 103). Given the low levels of MDR1 expression and the nearly ubiquitous expression of MRP1, lung cancer should be an excellent model in which to evaluate the role of MRP1-specific inhibitors.

Sarcomas represent another malignancy in which PGP expression seems to be important for drug resistance. Immunohistochemical studies of both soft-tissue sarcomas and osteosarcomas revealed a strong association between PGP expression, relapse-free survival and overall survival ${ }^{104,105}$. Other methodologies, however, have been used to substantiate and refute these findings, and there has been no consensus regarding the effect of PGP on survival in sarcomas ${ }^{106-110}$.

\section{Reversal of drug resistance in cancer}

Since the early 1980s, many agents have been investigated for their ability to reverse PGP-mediated multidrug resistance in cancer patients. Examples include verapamil, the phenothiazines, quinidine, quinacrine, quinine, amiodarone, several neuroleptics, tamoxifen, progesterone, cyclosporin A, dexverapamil, dexniguldipine, GF-902128, PSC-833 and VX-710. Agents already in use for other indications, but discovered to also inhibit PGP, were tested in the first clinical trials. Early speculation was replaced by reality as these agents were found to be weak inhibitors that were toxic at high doses ${ }^{111}$. In subsequent trials - most notably those with cyclosporin A and dexverapamil - it became clear that surrogate markers would be needed to evaluate efficacy. It has also become clear that a number of complications arise in treating cancer patients with these types of drug. Excellent reviews cataloguing completed trials are available $\mathrm{e}^{111-115}$.

Toxicity. The potential for bone-marrow and neurological toxicity were of concern when trials with PGP inhibitors were launched. Previous studies had shown that PGP was expressed and 'active' in haematopoietic stem cells ${ }^{116}$, and the discovery that PGP functioned at the $\mathrm{BBB}$ led to concern that inhibitors might damage the central nervous system. In support of this, the concentration of PGP substrates were increased in the central nervous systems of $M d r 1 a$ - and $M d r 1 b$-null mice ${ }^{49}$. Clinical findings did not, however, validate these concerns. Although MYELOSUPPRESSION has been observed in patients treated with PGP inhibitors, it is more likely to be caused by a pharmacokinetic interaction than by toxicity to stem cells. Very little toxicity to the central nervous system has been reported in patients treated with PGP inhibitors even with known neurotoxic compounds, such as the TAXANES or vinca alkaloids ${ }^{117}$. CEREBELLAR ATAXIA has been described in patients treated with PSC-833, tamoxifen or dexniguldipine administered alone ${ }^{115}$. It is unclear, however, if this ataxia occurs by inhibition of PGP at the blood-brain barrier.

A large number of trials have been conducted in patients with AML. Compared with historial controls, non-randomized trials showed an improved response in patients with relapsed or refractory AML, older patients with AML, and patients with MYELODYSPLASTIC SYNDROME who developed AML ${ }^{118-122}$. In one study, quinine treatment increased the complete response rate and disease-free survival in patients with PGP-positive leukaemic cells, but not in those with PGP-negative cells ${ }^{122}$. In addition, a large prospective randomized study of AML patients reported an increase in relapsefree and overall survival for patients receiving cyclosporin $\mathrm{A}^{123}$. Similar observations were made in patients with other PGP-expressing malignancies ${ }^{124,125}$.

Pharmacokinetic interactions. Interpretation of clinical trials involving inhibitors of MDR1/PGP has been confounded by their effects on the pharmacokinetics of anticancer drugs. Because PGP inhibitors increase serum levels of anticancer drugs ${ }^{112,113}$, researchers reduced the doses of anticancer drugs given to patients. The hope was that these dose reductions would result in similar drug concentrations. However, two studies administering paclitaxel in combination with PSC-833 found that a significant fraction of patients were undertreated ${ }^{177,126}$. Further evidence for 


\section{Box 1 | New P-glycoprotein inhibitors under development}

$X R-9576$, an anthranilic-acid-based drug, is a potent inhibitor of P-glycoprotein without apparent pharmacokinetic interaction. In clinical studies, a single intravenous dose completely inhibits rhodamine efflux from $\mathrm{CD}^{2} 6^{+}$circulating cells for up to 72 hours consistent with the observation that it is not a substrate for P-glycoprotein-mediated transport; and so might be expected to have a longer duration of action ${ }^{153}$.

$R-101933$ is a benzazepine derivative being developed as an oral P-glycoprotein inhibitor. In vitro studies have shown that the main metabolic pathway is not dependent on the cytochrome P450 CYP3A4, whereas clinical studies have found no effect on docetaxel pharmacokinetics.

$L Y-335979$ is a potent inhibitor that contains a cyclopropyldibenzosuberane moiety. Although the affinity of P-glycoprotein for LY-335979 is high, as with XR-9576, LY-335979 does not seem to be a substrate for P-glycoprotein. Clinical studies indicate that LY-335979 lacks significant pharmacokinetic interaction with plasma levels of doxorubicin, etoposide or paclitaxel ${ }^{154,155}$

$O C-1440935$ is a substituted diarylimidazole that was generated using combinatorial chemistry and high-throughput cell-based screening. Similar to the other, newer agents, it is highly potent, and does not seem to be a P-glycoprotein substrate. Pre-clinical studies indicate that it is orally bioavailable, lacks a pharmacokinetic interaction with plasma paclitaxel and does not inhibit CYP3A4.

GF-120918, an acridinecarboxamide derivative, fully reverses P-glycoproteinmediated resistance at concentrations as low as $30 \mathrm{nM}^{156}$ with a half-maximal inhibition at $50 \mathrm{nM}^{157}$, and has a minor effect on pharmacokinetics, except at very high modulator and doxorubicin levels, albeit with a more pronounced effect on doxorubicinol pharmacokinetics ${ }^{133}$. It can also block the half-transporter BCRP/MXR/ABCP, making it attractive as an inhibitor of more than one transporter ${ }^{157}$.

CD56+ CELLS

A subset of circulating

lymphocytes, known as natural

killer cells, that express the CD56

antigen. They are used to test

drug effectiveness in clinical

studies because they express

high levels of MDR1/P-

glycoprotein. underdosing can also be inferred from other trials ${ }^{83,119,127}$. If these are representative of most studies, and there is no reason to believe otherwise, it indicates that a significant fraction of patients have been underdosed. In a disease such as AML, this would have adverse consequences. Furthermore, another fraction of patients were probably overdosed, increasing the morbidity and mortality in those individuals receiving the PGP inhibitor.

The pharmacokinetic complications associated with PGP inhibitors might be due to the fact that they inhibit other proteins involved in drug metabolism, such as cytochrome P450. Or, for example, PSC-833 and cyclosporin A inhibit BSEP and reduce the secretion of bile salts, so they might reduce bile flow and slow hepatic excretion of chemotherapeutic agents ${ }^{128}$. Pharmacokinetic interactions seem to be most pronounced in patients treated with PSC-833 and cyclosporin $\mathrm{A}^{117,118,126,129,130}$, although they have been reported in patients treated with verapamil, dexverapamil, nifedipine and VX- 710 (REFS 112,131,132,165). The effect varies depending on the anticancer drug used in conjunction with the inhibitor, or even whether the parent drug or a metabolite is administered ${ }^{115,132-135}$.

After nearly 15 years and dozens of studies ${ }^{111,113-115}$, there is no definitive answer to the question: can a PGP inhibitor effectively reverse drug resistance in humans? The pharmacokinetic interactions observed with these agents have made it difficult to interpret efficacy. PGP inhibitors with fewer pharmacokinetic interactions are being developed, and surrogates are being used to determine the optimal dose of PGP inhibitor needed (BOX 1).

\section{Drug resistance reversal: surrogate assays}

To fully evaluate the in vivo efficacy of PGP inhibitors, surrogate assays have been developed that measure the extent of PGP inhibition. In the simplest assay, serum can be obtained from patients receiving a PGP inhibitor and assayed for its ability to either reverse multidrug resistance or increase drug accumulation in a PGP-overexpressing cell line $\mathrm{e}^{136,137}$.

Alternatively, CD56 $6^{+}$CELLS can be taken from patients undergoing therapy with a PGP inhibitor, and assayed for efflux of the PGP substrate, rhodamine-123 (FIG. 3) ${ }^{138,139}$. CD56 ${ }^{+}$cells express high levels of PGP
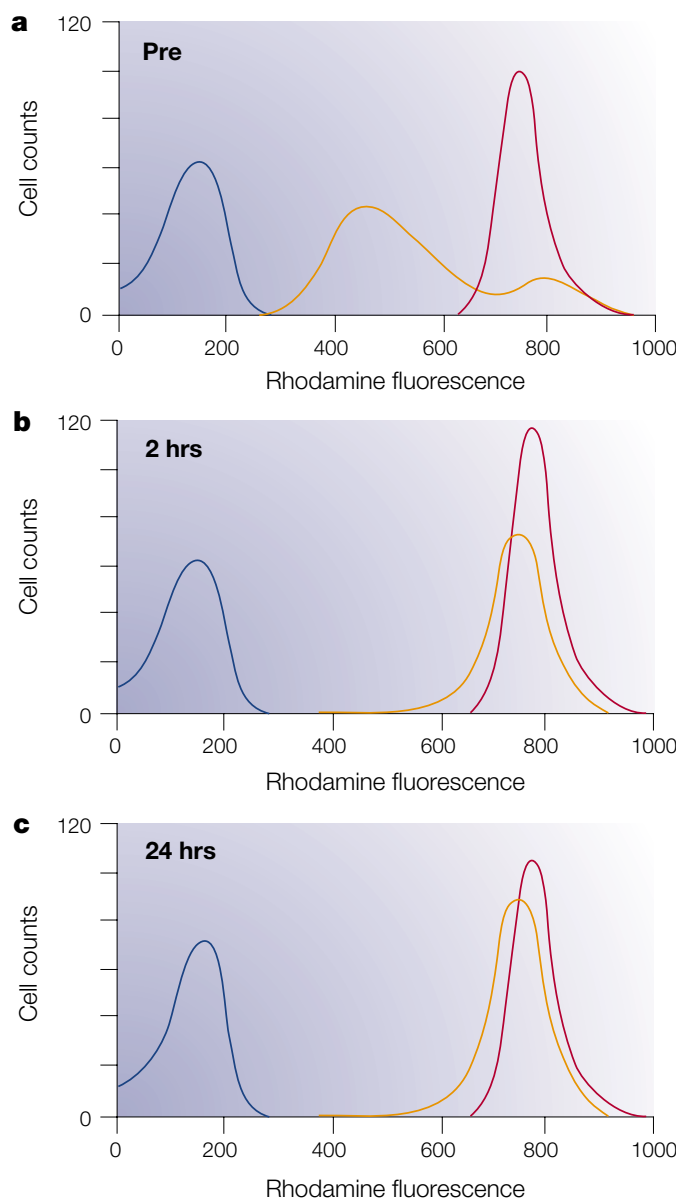

Figure 3 | A surrogate assay for PGP inhibition. This assay uses flow cytometry to test the ability of human CD56 ${ }^{+}$cells which express high levels of the efflux pump P-glycoprotein (PGP) - to retain the PGP substrate rhodamine after exposure to the efflux pump inhibitor PSC-833. The number of cells is indicated on the $y$ axis, and intracellular rhodamine fluorescence intensity is indicated on the $x$ axis. a | Cells that were never incubated in rhodamine have very low levels of fluorescence (blue line). When cells taken from a patient who has not yet been treated with PSC-833 are incubated in rhodamine, and then allowed a 30-min period of efflux in rhodamine-free medium they begin to lose fluorescence (yellow line). When the same cells are loaded with rhodamine and also treated with the PGP inhibitor PSC-833, they are highly fluorescent after 30 mins in rhodamine-free medium (red line). b. c | Cells taken from the same patient have high levels of intracellular fluorescence (red line) 2 and 24 hours after initiation of a continous intravenous infusion of PSC-833. 


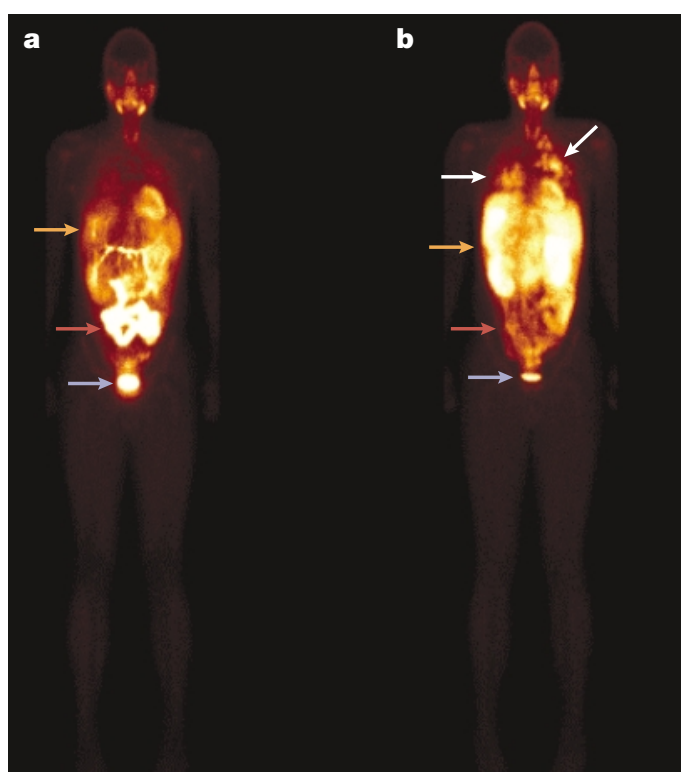

Figure 4 | 99mTc-sestamibi imaging to monitor PGP activity. Imaging analysis of the P-glycoprotein (PGP) substrate ${ }^{99 \mathrm{~m} T C} \mathrm{C}$-sestamibi after administration to a patient with adrenocortical cancer. Images were taken $\mathbf{a} \mid$ before and b | after the patient was given a single dose of the PGP inhibitor XR-9576 (Tariquidar). a | ${ }^{99 m}$ Tc-sestamibi accumulates in the gastrointestinal tract (red arrow), after excretion from the liver (orange arrow). The ${ }^{99 \mathrm{~m} T c-s e s t a m i b i}$ in the bladder (blue arrow) has been excreted by the kidneys. The liver is seen as a faint image, and no lung lesions are seen. b | After XR-9576 treatment, ${ }^{99 \mathrm{~m} T c} \mathrm{C}$-sestamibi accumulates in lung metastases, which appear as small labelled nodules in both lungs (white arrows). ${ }^{99 \mathrm{~m} T c}$-sestamibi also accumulates in the liver (orange arrow) as a consequence of PGP inhibition. The amount of effluxed ${ }^{99 m}$ Tc-sestamibi observed in the gastrointestinal tract (red arrow) and bladder (blue arrow) is markedly diminished compared with the left panel. The intense signal in the middle of the abdomen represents ${ }^{99 \mathrm{~m}} \mathrm{Tc}$-sestamibi accumulation in retroperitoneal lymph nodes. Images obtained 48 hours after the single dose show continued ${ }^{99 \mathrm{~m}} \mathrm{Tc}$-sestamibi retention in the liver (not shown).

and actively efflux rhodamine. This efflux is eliminated following administration of a PGP inhibitor. Neither of these assays, however, can be used to quantify accumulation of the chemotherapeutic agent in tumours.

Finally, ${ }^{99 \mathrm{~m} T c-s e s t a m i b i, ~ a ~ P G P ~ s u b s t r a t e ~ u s e d ~ i n ~ c a r-~}$ diac function imaging, can also be used to directly image PGP activity in both normal and tumour tissue (FIG. 4). Enhanced hepatic accumulation of ${ }^{99 \mathrm{~m}} \mathrm{Tc}$-sestamibi is now considered a surrogate marker for effective PGP inhibition $^{140-142}$. Several studies show a correlation between ${ }^{99 \mathrm{~m}} \mathrm{Tc}$-sestamibi efflux from tumours and PGP expression in cancer patients ${ }^{93-95}$. Furthermore, increased ${ }^{99 \mathrm{~m}} \mathrm{Tc}$-sestamibi accumulation in tumours has been observed following administration of PSC-833 and VX-710 (REFS 141,142). Similar results have been obtained with the newer PGP antagonist XR-9576 (Tariquida) (FIG. 4; BOX 1). However, it is important to remember that ${ }^{99 \mathrm{~m}} \mathrm{Tc}$-sestamibi is a substrate for MRP as well as for PGP ${ }^{143,144}$.

\section{Future prospects}

Detailed knowledge about the causes of drug resistance might make it possible, in the future, to predict the response of a human cancer to chemotherapy. Once all the main causes of drug resistance have been catalogued and molecular probes have been defined, it should be possible to determine their expression in individual cancer cells, obtained by either microdissection or from pathological sections. Even specific mechanisms of resistance expressed in a subpopulation of cells might be ascertained in this way. By enhancing detection capabilities, the likelihood of predicting the sensitivity or resistance of a cancer might be improved. DNA microarray analysis will improve our ability to determine which drug-resistance and drug-metabolizing genes are upregulated in different tumours, and these results can then be correlated with clinical responses to specific types of chemotherapy.

The primary goal of clinical trials has been to reverse existing drug resistance. A trial approach that has not been thoroughly examined is one that aims to prevent the emergence of drug resistance. In the laboratory, selection of resistant cells usually begins with low drug concentrations, which are then gradually advanced. Using high concentrations at the outset markedly reduces the number of resistant clones that are isolated. Because drug transporters effectively reduce drug exposure, they can facilitate development of drug resistance without themselves conferring high levels of resistance. So, a potentially effective strategy to prevent the emergence of drug resistance is to increase the intracellular concentration of chemotherapeutic agents by administering a transport inhibitor at the beginning of treatment. Several in vitro models support such a strategy. For example, in single-step selections, co-administration of an inhibitor has been shown to reduce the rate of mutations that cause doxorubicin resistance to a tenth of the rate in the absence of an inhibitor, while suppressing the emergence of PGP-expressing resistant cells ${ }^{145}$.

It must be emphasized, however, that in a trial design that aims to prevent the emergence of drug resistance, significant differences in patient response rates might not be observed. Instead, only differences in the rate of relapse and time to progression would be anticipated. The latter would occur because a prevention strategy does not target most of the cells in a tumour, but only a small subpopulation, and hence does not significantly alter the initial cell kill. Such an outcome has been reported in a study in which cyclosporin $\mathrm{A}$ was added to daunorubicin and Ara-C in the initial treatment of patients with $\mathrm{AML}^{123}$. Although this combination regimen had no impact on the complete remission rate, the overall survival and the disease-free survival were improved.

Clinical evidence indicates that PGP expression can be induced by drug exposure. In one study in which biopsies were obtained surgically at the beginning and end of a lung perfusion with doxorubicin, PGP levels increased 3-15-fold, showing that tumours adjust rapidly to anticancer drugs ${ }^{146}$. Similar observations have been made in patients receiving the histone 
deacetylase inhibitor FR-901228, an experimental anticancer agent known to be an excellent PGP substrate ${ }^{147}$. Administration of FR-901228 results in rapid induction of PGP expression in malignant cells from patients with T-cell lymphoma (S.E.B., unpublished observations). These studies indicate that strategies to block upregulation of PGP might also be useful in the clinic.

Finally, although it is common for cancer cells to become multidrug resistant, normal human tissues remain sensitive to the toxic effects of chemotherapy. This indicates that multidrug-resistance genes might be used to protect normal tissues against the cytotoxic effects of anticancer drugs. In mice, transfer of genes that encode Mdr1 (REF. 148) and methotrexate-resistance proteins ${ }^{149}$ protects bone marrow from the toxic effects of anticancer drugs such as paclitaxel and methotrexate. Several clinical trials have been undertaken in cancer patients who are undergoing autologous bonemarrow transplants to assay the ability of bone-marrow cells that transgenically express MDR1 to survive after chemotherapy ${ }^{150}$. However, the finding that mice expressing $M d r 1$ from a retroviral vector developed myelodysplasia ${ }^{151}$ indicates that more needs to be known about the effects of drug-resistance genes on normal haematopoietic function before this approach can be undertaken routinely in cancer patients.

Nearly three decades after the description of active outward transport of daunorubicin in drugresistant tumour cells ${ }^{152}$, the study of multidrug resistance is still work in progress. Many questions must be answered about the mechanisms by which cancer cells elude chemotherapy, and known mechanisms of multidrug resistance must undergo further analysis in clinical trials. One conclusion is certain - the mutability and heterogeneity of cancer cells will always provide them with ways to overcome resistance, no matter how new or important the anticancer drug.
1. Gorre, M. E. et al. Clinical resistance to STI-571 cancer therapy caused by BCR-ABL gene mutation or amplification. Science 293, 876-880 (2001).

2. Pluen, A. et al. Role of tumor-host interactions in interstitial diffusion of macromolecules: cranial vs. subcutaneous tumors. Proc. Natl Acad. Sci. USA 98 4628-4633 (2001).

3. Jain, R. K. Delivery of molecular and cellular medicine to solid tumors. Adv. Drug Deliv. Rev. 46, 149-168 (2001).

solid tumors. Adv. Drug Deliv. Rev. 46, 149-168 (2001). angiogenic therapy: a new paradigm for combination therapy. Nature Med. 7, 987-989 (2001).

5. Green, S. K., Frankel, A. \& Kerbel, R. S. Adhesiondependent multicellular drug resistance. Anticancer Drug Des. 14, 153-168 (1999).

6. Durand, R. E. \& Olive, P. L. Resistance of tumor cells to chemo- and radiotherapy modulated by the threedimensional architecture of solid tumors and spheroids. Methods Cell Biol. 64, 211-233 (2001).

7. Dean, M., Rzhetsky, A. \& Alliknets, R. The human ATPbinding cassette (ABC) transporter superfamily.Genome binding cassette (ABC) transp
Res. 11, 1156-1166 (2001). Res. 11, 1156-1166 (2001).
Most recent update of the ABC transporter family, emphasizing genetic disorders that result from disruption of $A B C$ genes.

8. Ambudkar, S. V. et al. Biochemical, cellular, and pharmacological aspects of the multidrug transporter. Annu. Rev. Pharmacol. Toxicol. 39, 361-398 (1999).

9. Shen, D. W., Goldenberg, S., Pastan, I. \& Gottesman, M M. Decreased accumulation of $\left[{ }^{14} \mathrm{C}\right]$ carboplatin in human cisplatin-resistant cells results from reduced energy-dependent uptake. J. Cell Physiol. 183 energy-dependent

10. Shen, D., Pastan, I. \& Gottesman, M. M. Cross-resistance to methotrexate and metals in human cisplatin-resistant cell lines results from a pleiotropic defect in accumulation of these compounds associated with reduced plasma membrane binding proteins. Cancer Res. 58, 268-275 (1998).

11. Schuetz, E. G., Beck, W. T. \& Schuetz, J. D. Modulators and substrates of P-glycoprotein and cytochrome P4503A coordinately up-regulate these proteins in human colon carcinoma cells. Mol. Pharmacol. 49, 311-318 colon Cari

12. Synold, T. W., Dussault, I. \& Forman, B. M. The orphan nuclear receptor SXR coordinately regulates drug metabolism and efflux. Nature Med. 7, 584-590 (2001). This paper provides direct evidence for coordination of drug-detoxifying systems through activation of a single transcription factor, SXR.

13. Liu, Y. Y., Han, T. Y., Giuliano, A. E. \& Cabot, M. C. Ceramide glycosylation potentiates cellular multidrug resistance. FASEB J. 15, 719-730 (2001).

14. Juliano, R.L. \& Ling, V. A surface glycoprotein modulating drug permeability in Chinese hamster ovary cell mutants. drug permeability in Chinese hamster ovary cell
Biochim. Biophys. Acta 455, 152-162 (1976).

15. Ueda, K., Cardarelli, C., Gottesman, M. M. \& Pastan, I. Expression of a full-length cDNA for the human MDR1 gene confers resistance to colchicine, doxorubicin, and vinblastine. Proc. Natl Acad. Sci. USA 84, 3004-3008 (1987).

16. Chen, C.J. et al. Internal duplication and homology with bacterial transport proteins in Mdr-1 (P-glycoprotein) gene from multidrug-resistant human cells. Cell 47, 371-380 (1986).

\section{Description of the sequence of the MDR1}

(P-glycoprotein) cDNA and its homology to two (P-glycoprotein) CDNA and its homology to two members of the $A B C$ transporter family.

17. Senior, A. E. \& Bhagat, S. P-glycoprotein shows strong catalytic cooperativity between the two nucleotide sites. Biochemistry 37, 831-836 (1998).

18. Ramachandra, M. et al. Human P-glycoprotein exhibits reduced affinity for substrates during a catalytic transition state. Biochemistry 37, 5010-5019 (1998).

19. Sauna, Z. E. \& Ambudkar, S. V. Evidence for a requirement for ATP hydrolysis at two distinct steps during a single turnover of the catalytic cycle of human P-glycoprotein Proc. Natt Acad. Sci. USA 97, 2515-2520 (2000).

20. Cole, S.P.C. et al. Overexpression of a transporter gene in a multidrug-resistant human lung cancer cell line. Science 258, 1650-1654 (1993).

21. Loe, D. W., Deeley, R. G. \& Cole, S. P. Characterization of vincristine transport by the $M($,$) 190,000 multidrug$ resistance protein (MRP): evidence for cotransport with reduced glutathione. Cancer Res. 58, 5130-5136 (1998).

22. Jedlitschky, G. et al. Transport of glutathione, glucuronate, and sulfate conjugates by the MRP geneencoded conjugate export pump. Cancer Res. $\mathbf{5 6}$ 988-994 (1996).

Observations that led to the conclusion that MRP was a broad-specificity organic anion transporter.

23. Muller, M. et al. Overexpression of the gene encoding the multidrug resistance-associated protein results in increased ATP-dependent glutathione S-conjugate transport. Proc. Natl Acad. Sci. USA 91, 13033-13037 (1994).

24. Borst, P., Evers, R., Kool, M. \& Wijnholds, J. A family of drug transporters: the multidrug resistance-associated proteins. J. Natl Cancer Inst. 92, 1295-1302 (2000).

25. Miyake, K. et al. Molecular cloning of cDNAs which are highly overexpressed in mitoxantrone-resistant cells: demonstration of homology to $\mathrm{ABC}$ transport genes. Cancer Res. 59. 8-13 (1999).

26. Doyle, L. A. et al. A multidrug resistance transporter from human MCF-7 breast cancer cells. Proc. Natl Acad. Sci. USA 95, 15665-15670 (1998).

27. Allikmets, R., Schriml, L. M., Hutchinson, A., RomanoSpica, V. \& Dean, M. A human placenta-specific ATPbinding cassette gene (ABCP) on chromosome $4 \mathrm{q} 22$ that is involved in multidrug resistance. Cancer Res. $\mathbf{5 8}$ 5337-5339 (1998).

28. Honjo, Y. et al. Acquired mutations in the MXR/BCRP/ABCP gene alter substrate specificity in MXR/BCRP/ABCPoverexpressing cells. Cancer Res. (in the press).

29. Komatani, H. et al. Identification of breast cancer resistant protein/mitoxantrone resistance/placenta-specific, ATPbinding cassette transporter as a transporter of NB-506 and
$\mathrm{J}-107088$, topoisomerase I inhibitors with an indolocarbazole structure. Cancer Res. 61, 2827-2832 (2001).

30. Childs, S., Yeh, R. L., Hui, D. \& Ling, V. Taxol resistance mediated by transfection of the liver-specific sister gene of P-glycoprotein. Cancer Res. 58, 4160-4167 (1998).

31. Smit, J. J. et al. Homozygous disruption of the murine $M d r 2$ P-glycoprotein gene leads to a complete absence of phospholipid from bile and to liver disease. Cell 75, 451-462 phospholp
(1993).

32. Zhou, Y., Gottesman, M. M. \& Pastan, I. Studies of human MDR1-MDR2 chimeras demonstrate the functional exchangeability of a major transmembrane segment of the multidrug transporter and phosphatidylcholine flippase. Mo Cell Biol. 19, 1450-1459 (1999).

33. Borst, P., Zelcer, N. \& van Helvoort, A. ABC transporters in lipid transport. Biochim. Biophys. Acta 1486, 128-144 (2000).

34. Laing, N. M. et al. Amplification of the ATP-binding cassette transporter gene is functionally linked with enhanced efflux of estramustine in ovarian carcinoma cells. Cancer Res. $\mathbf{5 8}$ 1332-1337 (1998).

35. Vulevic $B$ et al Cloning and characterization of human adenosine $5^{\prime}$-triphosphate-binding cassette, sub-family $\mathrm{A}$, transporter 2 (ABCA2). Cancer Res. 61, 3339-3347 (2001).

36. Scheffer, G. L., Schroeijers, A. B., Izquierdo, M. A., Wiemer, E. A. \& Scheper, R. J. Lung resistance-related protein/major vault protein and vaults in multidrug-resistant cancer. Curr. Opin. Oncol. 12, 550-556 (2000).

37. Kool, M. et al. MRP3, an organic anion transporter able to transport anti-cancer drugs. Proc. Natl Acad. Sci. USA 96 6914-6919 (1999).

38. Belinsky, M. G. \& Kruh, G. D. MOAT-E (ARA) is a full-length MRP/CMOAT subfamily transporter expressed in kidney and liver. Br. J. Cancer 80, 1342-1349 (1999).

39. Chen, Z. S., Lee, K. \& Kruh, G. D. Transport of cyclic nucleotides and estradiol $17-\beta$-D-glucuronide by multidrug resistance protein 4: resistance to 6-mercaptopurine and 6-thioguanine. J. Biol. Chem. 276 33747-33754 (2001).

40. Schuetz, J. D. et al. MRP4: a previously unidentified factor in resistance to nucleoside-based antiviral drugs. Nature Med. 5, 1048-1051 (1999).

41. Wijnholds, J. et al. Multidrug-resistance protein 5 is a multispecific organic anion transporter able to transport multispecific organic anion transporter able to trans. 7476-7481 (2000).

42. Jedlitschky, G., Burchell, B. \& Keppler, D. The multidrug resistance protein 5 functions as an ATP-dependent export pump for cyclic nucleotides. J. Biol. Chem. 275 30069-30074 (2000).

43. Struk, B. et al. Mutations of the gene encoding the transmembrane transporter protein ABC-C6 cause pseudoxanthoma elasticum. J. Mol. Med. 78, 282-286 (2000).

44. Bergen, A. A. et al. Mutations in ABCC6 cause pseudoxanthoma elasticum. Nature Genet. 25, 228-231 (2000)

45. Ringpfeil, F., Lebwohl, M. G., Christiano, A. M. \& Uitto, J. Pseudoxanthoma elasticum: mutations in the MRP6 gene 
encoding a transmembrane ATP-binding cassette (ABC) transporter. Proc. Natl Acad. Sci. USA 97, 6001-6006 (2000).

46. Le Saux, O. et al. Mutations in a gene encoding an ABC transporter cause pseudoxanthoma elasticum. Nature Genet. 25, 223-227 (2000).

47. Gerloff, T. et al. The sister of P-glycoprotein represents the canalicular bile salt export pump of mammalian liver. J. Biol. Chem. 273, 10046-10050 (1998).

48. Lecureur, V. et al. Cloning and expression of murine sister of P-glycoprotein reveals a more discriminating transporter P-glycoprotein reveals a more discriminating transporter
than MDR1/P-glycoprotein. Mol. Pharmacol. 57, 24-35 (2000).

49. Schinkel, A. H., Wagenaar, E., Mol, C. A. \& van Deemter, L. $P$-glycoprotein in the blood-brain barrier of mice influences the brain penetration and pharmacological activity of many drugs. J. Clin. Invest. 97, 2517-2524 (1996).

Follow-up study to the landmark observation that disruption of the PGPs failed to evoke a disease phenotype, but did render mice extraordinarily sensitive to ivermectin. This implicated a role for PGP in the blood-brain barrier.

50. Xie, R., Hammarlund-Udenaes, M. de Boer, A. G. \& de Lange, E. C. The role of P-glycoprotein in blood-brain barrier transport of morphine: transcortical microdialysis studies in Mdr1a $\left(^{(-)}\right)$and Mdr1a $\left(^{+++}\right)$mice. Br. J. Pharmacol. 128, 563-568 (1999).

51. Rao, V. V. et al. Choroid plexus epithelial expression of MDR1 P glycoprotein and multidrug resistance-associated protein contribute to the blood-cerebrospinal-fluid drugpermeability barrier. Proc. Natl Acad. Sci. USA $\mathbf{9 6}$ 3900-3905 (1999).

Description of MRP and PGP localization in the epithelium of choroid plexus, and prediction of epithelium of choroid plexus, and prediction of
distinctive roles in the blood-cerebrospinal-fluid barrier.

52. Cordon-Cardo, C. et al. Expression of the multidrug resistance gene product (P-glycoprotein) in human norm and tumor tissues. J. Histochem. Cytochem. 38 1277-1287 (1990).

53. Jonker, J. W. et al. Role of breast cancer resistance protein in the bioavailability and fetal penetration of topotecan. J. Natl Cancer Inst. 92, 1651-1656 (2000).

54. Maliepaard, M. et al. Subcellular localization and distribution of the breast cancer resistance protein transporter in normal human tissues. Cancer Res. 61 3458-3464 (2001).

55. St-Pierre, M. V. et al. Expression of members of the multidrug resistance protein family in human term placenta. Am. J. Physiol. 279, R1495-R1503 (2000).

56. Schinkel, A. H. et al. Normal viability and altered pharmacokinetics in mice lacking Mdr1-type (drugtransporting) P-glycoproteins. Proc. Natl Acad. Sci. USA 94 4028-4033 (1997).

\section{Clear demonstration that PGP affects the tissue} distribution and retention of drugs other than anticancer agents.

57. Scheffer, G. L. et al. Specific detection of multidrug resistance proteins MRP1, MRP2, MRP3, MRP5, and MDR3 P-glycoprotein with a panel of monoclonal antibodies. Cancer Res. 60, 5269-5277 (2000).

58. Kool, M., van der Linden, M., de Haas, M., Baas, F. \& Borst, P. Expression of human MRP6, a homologue of the multidrug resistance protein gene MRP1, in tissues and cancer cells. Cancer Res. 59, 175-182 (1999).

59. Konig, J Nies, A. T Cui, Y Leier I \& Keppler, D. Conjugate export pumps of the multidrug resistance protein (MRP) family: localization, substrate specificity, and MRP2mediated drug resistance. Biochim. Biophys. Acta 1461 377-394 (1999).

60. Paulusma, C. C. et al. Congenital jaundice in rats with a mutation in a multidrug resistance-associated protein gene. Science 271, 1126-1128 (1996).

61. Ito, K. et al. Molecular cloning of canalicular multispecific organic anion transporter defective in EHBR. Am. J. Physio. 272, G16-G22 (1997).

62. Kartenbeck, J., Leuschner, U., Mayer, R. \& Keppler, D. Absence of the canalicular isoform of the MRP geneencoded conjugate export pump from the hepatocytes in Dubin-Johnson syndrome. Hepatology 23, 1061-1066 (1996)

63. Paulusma, C. C. et al. A mutation in the human canalicular multispecific organic anion transporter gene causes the Dubin-Johnson syndrome. Hepatology 25, 1539-1542 (1997)

64. Strautnieks, S. S. et al. A gene encoding a liver-specific ABC transporter is mutated in progressive familial intrahepatic cholestasis. Nature Genet. 20, 233-238 (1998).

65. Wang, R. et al. Targeted inactivation of sister of P-glycoprotein gene (Spgp) in mice results in nonprogressive but persistent intrahepatic cholestasis. Proc. Natl Acad. Sci. USA 98, 2011-2016 (2001).

66. Ruetz, S. \& Gros, P. Phosphatidylcholine translocase: a physiological role for the Mdr2 gene. Cell 77, 1071-1081 (1994).

First physiological role for an MDR gene is convincingly described.

67. de Vree, J. M. et al. Mutations in the MDR3 gene cause progressive familial intrahepatic cholestasis. Proc. Natl Acad. Sci. USA 95, 282-287 (1998).

68. Mayer, U. et al. Full blockage of intestinal P-glycoprotein and extensive inhibition of blood-brain barrier P-glycoprotein by oral treatment of mice with PSC-833. J. Clin. Invest. 100 2430-2436 (1997)

69. Greiner, B. et al. The role of intestinal P-glycoprotein in the interaction of digoxin and rifampin. J. Clin. Invest. 104, 147-153 (1999)

70. Lown, K. S. et al. Role of intestinal P-glycoprotein (Mdr1) in interpatient variation in the oral bioavailability of cyclosporine. Clin. Pharmacol. Ther. 62, 248-260 (1997).

71. Sparreboom, A. et al. Limited oral bioavailability and active epithelial excretion of paclitaxel (Taxol) caused by P-glycoprotein in the intestine. Proc. Natl Acad. Sci. USA 94, 2031-2035 (1997).

72. Evers, R. et al. Basolateral localization and export activity of the human multidrug resistance-associated protein in polarized pig kidney cells. J. Clin. Invest. 97, 1211-1218 (1996).

73. Wijnholds, J. et al. Increased sensitivity to anticancer drugs and decreased inflammatory response in mice lacking the multidrug resistance-associated protein. Nature Med. $\mathbf{3}$ 1275-1279 (1997)

74. Dietrich, C. G., de Waart, D. R., Ottenhoff, R., Schoots, I. G. \& Elferink, R. P. Increased bioavailability of the food-derived carcinogen 2-amino-1-methyl-6-phenylimidazo[4,5-b] pyridine in Mrp2-deficient rats. Mol. Pharmacol. 59, 974-980 (2001)

75. Fojo, A.T. et al. Expression of a multidrug resistance gene in human tumors and tissues. Proc. Natl Acad. Sci. USA 84, 265-269 (1987)

76. Goldstein, L. J. et al. Expression of a multidrug resistance gene in human cancers. J. Natl Cancer Inst. 81, 116-124 (1989).

77. van den Heuvel-Eibrink, M. M., Sonneveld, P. \& Pieters, R. The prognostic significance of membrane transportassociated multidrug resistance (MDR) proteins in leukemia. Int. J. Clin. Pharmacol. Ther. 38, 94-110 (2000).

78. Beck, W.T. et al. Methods to detect P-glycoprotein-associated multidrug resistance in patients' tumors: consensus recommendations. Cancer Res. 56, 3010-3020 (1996).

79. Hipfner, D. R. et al. Epitope mapping of monoclonal antibodies specific for the 190-kDa multidrug resistance protein (MRP). Br. J. Cancer 78, 1134-1140 (1998).

80. Nooter, K. et al. Expression of the multidrug resistanceassociated protein (MRP) gene in human cancers. Clin. Cancer Res. 1, 1301-1310 (1995).

81. Leith, C. P. et al. Frequency and clinical significance of the expression of the multidrug resistance proteins MDR1/ P-glycoprotein, MRP1, and LRP in acute myeloid leukemia: a Southwest Oncology Group Study. Blood 94, 1086-1099 (1999).

Assay of leukaemic cells obtained from 351 patients with acute myelogenous leukaemia, and confirmation that PGP expression and function correlate with a decreased complete remission rate and an increased rate of resistant disease.

82. Han, K. et al. Expression of functional markers in acute nonlymphoblastic leukemia. Acta Haematol. 104, 174-180 (2000).

83. Dorr, R. et al. Phase $\mathrm{l} / \mathrm{ll}$ study of the P-glycoprotein modulator PSC 833 in patients with acute myeloid leukemia. J. Clin. Oncol. 19, 1589-1599 (2001).

84. van der Kolk, D. M. et al. P-glycoprotein and multidrug resistance protein activities in relation to treatment outcome in acute myeloid leukemia. Clin. Cancer Res. 6, 3205-3214 (2000).

85. Legrand, O., Simonin, G., Beauchamp-Nicoud, A., Zittoun, R \& Marie, J. P. Simultaneous activity of MRP1 and PGP is correlated with in vitro resistance to daunorubicin and with in vivo resistance in adult acute myeloid leukemia. Blood $\mathbf{9 4}$, 1046-1056 (1999).

86. Michieli, M. et al. P-glycoprotein, lung resistance-related protein and multidrug resistance associated protein in de novo acute non-lymphocytic leukaemias: biological and clinical implications. Br. J. Haematol. 104, 328-335 (1999).

87. Broxterman, H. J. et al. Do P-glycoprotein and major vault protein (MVP/LRP) expression correlate with in vitro daunorubicin resistance in acute myeloid leukemia? Leukemia 13, 258-265 (1999).
88. Tidefelt, U. et al. P-glycoprotein inhibitor valspodar (PSC-833) increases the intracellular concentrations of daunorubicin in vivo in patients with $\mathrm{P}$-glycoprotein-positive acute myeloid leukemia. J. Clin. Oncol. 18, 1837-1844 (2000)

89. Burger, H. et al. Expression of the multidrug resistanceassociated protein (MRP) in acute and chronic leukemias. Leukemia 8, 990-997 (1994).

90. Filipits, M. et al. Multidrug resistance-associated protein in acute myeloid leukemia: no impact on treatment outcome. Clin. Cancer Res. 3, 1419-1425 (1997)

91. Ross, D. D., Karp, J. E., Chen, T. T. \& Doyle, L. A. Expression of breast cancer resistance protein in blast cells from patients with acute leukemia. Blood 96, 365-368 (2000)

92. Trock, B. J., Leonessa, F. \& Clarke, R. Multidrug resistance in breast cancer: a meta-analysis of MDR1/GP170 expression and its possible functional significance. J. Natl Cancer Inst. 89, 917-931 (1997).

\section{Meta-analysis showing PGP expression in} approximately $40 \%$ of breast cancer samples, and a

correlation with decreased treatment response.

Vecchio, S. D. et al. In vivo detection of multidrug-resistant
(MDR1) phenotype by $99 \mathrm{~m}$ sestamibi scan in untreated breas (MDR1) phenotype by 99m sestamibi scan in untreated b Study showing an inverse correlation between MRK16 binding to breast cancer samples and ${ }^{99 \mathrm{~m}} \mathrm{Tc}-$ sestamibi retention in breast cancers.

94. Sun, S. S. et al. Expression of mediated P-glycoprotein multidrug resistance related to Tc-99m MIBI scintimammography results. Cancer Lett. 153, 95-100 (2000).

95. Kao, C. H. et al. P-glycoprotein and multidrug resistancerelated protein expressions in relation to technetium-99m methoxyisobutylisonitrile scintimammography findings. Cancer Res. 61, 1412-1414 (2001).

96. Dexter, D. W. et al. Quantitative reverse transcriptasepolymerase chain reaction measured expression of MDR1 and MRP in primary breast carcinoma. Clin. Cancer Res. 4 1533-1542 (1998).

97. Filipits, M. et al. MRP and MDR1 gene expression in primary breast carcinomas. Clin. Cancer Res. 2, 1231-1237 (1996).

98. Nooter, K. et al. The prognostic significance of expression of the multidrug resistance-associated protein (MRP) in primary breast cancer. Br. J. Cancer 76, 486-493 (1997).

99. Oka, M. et al. The clinical role of MDR1 gene expression in human lung cancer. Anticancer Res. 17, 721-724 (1997).

100. Savaraj, N. et al. Multidrug-resistant gene expression in small-cell lung cancer. Am. J. Clin. Oncol. 20, 398-403 (1997).

101. Young, L. C. et al. Expression of multidrug resistance protein-related genes in lung cancer: correlation with drug response. Clin. Cancer Res. 5, 673-680 (1999).

102. Nooter, K. et al. Expression of the multidrug resistanceassociated protein (MRP) gene in primary non-small-cell lung cancer. Ann. Oncol. 7, 75-81 (1996).

103. Wright, S. R. et al, Immunohistochemical detection of multidrug resistance protein in human lung cancer and normal lung. Clin. Cancer Res. 4, 2279-2289 (1998).

104. Chan, H. S. L., Thorner, P. S., Haddad, G. \& Ling, V. Immunohistochemical detection of P-glycoprotein prognostic correlation in soft tissue sarcoma of childhood. J. Clin. Oncol. 50, 2818-2822 (1990).

105. Chan, H. S., Grogan, T. M., Haddad, G., DeBoer, G. \& Ling, V. P-glycoprotein expression: critical determinant in the response to osteosarcoma chemotherapy. J. Nat/ Cancer response to osteosarcoma chen
Inst. 89, 1706-1715 (1997).

106. Perri, T. et al. Effect of P-glycoprotein expression on outcome in the Ewing family of tumors. Pediatr. Hematol. Oncol. 18, 325-334 (2001).

107. Baldini, N. et al. Expression of P-glycoprotein in high-grade osteosarcomas in relation to clinical outcome. N. Engl. J. Med. 333, 1380-1385 (1995).

108. Coley, H. M. et al. Incidence of P-glycoprotein overexpression and multidrug resistance (MDR) reversal in adult soft tissue sarcoma. Eur. J. Cancer 36, 881-888 (2000).

109. Wunder, J. S. et al. MDR1 gene expression and outcome in osteosarcoma: a prospective, multicenter study. J. Clin. Oncol. 18, 2685-2694 (2000).

110. Kuttesch, J. F. et al. P-glycoprotein expression at diagnosis may not be a primary mechanism of therapeutic failure in childhood rhabdomyosarcoma. J. Clin. Oncol. 14, 886-900 (1996).

111. Ferry, D. R., Traunecker, H. \& Kerr, D. J. Clinical trials of P-glycoprotein reversal in solid tumours. Eur. J. Cancer 32A 1070-1081 (1996).

112. Kerr, D. J. et al. The effect of verapamil on the pharmacokinetics of adriamycin. Cancer Chemother. Pharmacol. 18, 239-242 (1986). 
113. Fisher, G. A. \& Sikic, B. I. Clinical studies with modulators of multidrug resistance. Hematol. Oncol. Clin. N. Am. 9 363-382 (1995).

114. Bradshaw, D. M. \& Arceci, R. J. Clinical relevance of transmembrane drug efflux as a mechanism of multidrug resistance. J. Clin. Oncol. 16, 3674-3690 (1998).

115. Fisher, G. A., Lum, B. L., Hausdorff, J. \& Sikic, B. I. Pharmacological considerations in the modulation of multidrug resistance. Eur. J. Cancer 32A, 1082-1088 (1996).

116. Chaudhary, P. M. \& Roninson, I. B. Expression and activity of P-glycoprotein, a multidrug efflux pump, in human
hematopoietic stem cells. Cell 66, 85-94 (1991). Early paper that highlights the role of P-glycoprotein in normal cells.

117. Chico, I. et al. Phase I study of infusional paclitaxel in combination with the P-glycoprotein antagonist PSC- 833. J. Clin. Oncol. 19, 832-842 (2001).

118. Advani, R. et al. Treatment of refractory and relapsed acute myelogenous leukemia with combination chemotherapy plus the multidrug resistance modulator PSC-833 (Nalspodar). Blood 93, 787-795 (1999).

119. Kornblau, S. M. et al. Phase I study of mitoxantrone plus etoposide with multidrug blockade by SDZ PSC-833 in relapsed or refractory acute myelogenous leukemia. J. Clin. Oncol. 15, 1796-1802 (1997).

120. List, A. F. et al. Phase I/I trial of cyclosporine as a chemotherapy-resistance modifier in acute leukemia. J. Clin Oncol. 11, 1652-1660 (1993).

121. Lee, E. J. et al. Parallel phase I studies of daunorubicin given with cytarabine and etoposide with or without the multidrug resistance modulator PSC-833 in previously untreated patients 60 years of age or older with acute myeloid leukemia: results of cancer and leukemia group myeloid leukemia: results of cancer and leuke B study 94.
(1999).

122. Solary, E. et al. Combination of quinine as a potential reversing agent with mitoxantrone and cytarabine for the treatment of acute leukemias: a randomized multicenter study. Blood 88, 1198-1205 (1996).

123. List, A. F. et al. Benefit of cyclosporine (CsA) modulation of drug resistance in patients with poor-risk acute myeloid leukemia: a Southwest Oncology Group (SWOG) Study. Blood 98, 3212-3220 (2001).

These long-term results indicate a survival advantage of treatment of acute myelogenous leukaemia with of treatment of acute myelogenous leukaemia with
daunomycin in combination with the PGP antagonist cyclosporin A.

124. Sonneveld, P. et al. Modulation of multidrug-resistant multiple myeloma by cyclosporin. Lancet $\mathbf{3 4 0}$, 255-259 (1992).

125. Millward, M. J. et al. Oral verapamil with chemotherapy for advanced non-small cell lung cancer: a randomised study. Br. J. Cancer 67, 1031-1035 (1993).

126. Fracasso, P. M. et al. Phase I study of paclitaxel in combination with a multidrug resistance modulator, PSC-833 (Valspodar), in refractory malignancies. J. Clin. Oncol. 18, 1124 (2000).

127. Fracasso, P. M. et al. Phase II study of paclitaxel and valspodar (PSC-833) in refractory ovarian carcinoma: gynecologic oncology group study. J. Clin. Oncol. 19 2975-2982 (2001).

128. Bohme, M., Buchler, M., Muller, M. \& Keppler, D. Differential inhibition by cyclosporins of primary-active ATP-dependent transporters in the hepatocyte canalicular membrane. FEBS Lett. 333, 193-196 (1993).

129. Lum, B. L. et al. Alteration of etoposide pharmacokinetics and pharmacodynamics by cyclosporine in a phase I trial to modulate multidrug resistance. J. Clin. Oncol. 10 modulate multidrug

130. Bartlett, N. L. et al. Phase I trial of doxorubicin with cyclosporine as a modulator of multidrug resistance. J. Clin. Oncol. 12, 835-842 (1994).

131. Rowinsky, E. K. et al. Phase I and pharmacokinetic study of paclitaxel in combination with biricodar, a novel agent that reverses multidrug resistance conferred by overexpression of both MDR1 and MRP. J. Clin. Oncol. 16, 2964-2976. (1998).

132. Wilson, W. H. et al. Phase I and pharmacokinetic study of the multidrug resistance modulator dexverapamil with EPOCH chemotherapy. J. Clin. Oncol. 13, 1985-1994 (1995).
133. Sparreboom, A. et al. Clinical pharmacokinetics of doxorubicin in combination with GF120918, a poten inhibitor of MDR1 P-glycoprotein. Anticancer Drugs 10 719-728 (1999).

134. Advani, R. et al. A phase I trial of doxorubicin, paclitaxel, and valspodar (PSC- 833), a modulator of multidrug resistance. Clin. Cancer Res. 7, 1221-1229 (2001).

135. Kang, M. H. et al. The P-glycoprotein antagonist PSC- 833 increases the plasma concentrations of $6 \alpha$-hydroxypaclitaxel, a major metabolite of paclitaxel. Clin. Cancer Res. 7, 1610-1617 (2001).

136. Solary, E. et al. Sufficient levels of quinine in the serum circumvent the multidrug resistance of the human leukemic cell line K562/ADM. Cancer 68, 1714-1719 (1991).

137. Minami, H. et al. Phase I study of intravenous PSC-833 and doxorubicin: reversal of multidrug resistance. Jpn. J. Cancer Res. 92, 220-230 (2001).

138. Robey, R. et al. Efflux of rhodamine from $\mathrm{CD}^{+} 6^{+}$cells as a surrogate marker for reversal of P-glycoprotein-mediated drug efflux by PSC-833. Blood 93, 306-314 (1999).

139. Witherspoon, S. M. et al. Flow cytometric assay of modulation of P-glycoprotein function in whole blood by the multidrug resistance inhibitor GG918. Clin. Cancer Res. 2, 7-12 (1996).

140. Luker, G.D., Facasso, P.M., Dobkin, J. \& Piwnica-Worms, D. Modulation of the multidrug resistance P-glycoprotein: detection with technetium-99m-sestamibi in vivo. J. Nucl. Med. 38, 369-372 (1997).

Promising study showing the ability of PSC-833 to increase liver retention of ${ }^{99 \mathrm{~m}} \mathrm{Tc}$-sestamibi as a surrogate for PGP inhibition.

141. Chen, C. C. et al. Detection of in vivo P-glycoprotein inhibition by PSC-833 using Tc-99m sestamibi. Clin. Cancer Res. 4, 545-552 (1997).

142. Peck, R. A. et al. Phase I and pharmacokinetic study of the novel MDR1 and MRP1 inhibitor biricodar administered alone and in combination with doxorubicin. J. Clin. Oncol. 19, 3130-3141 (2001).

143. Hendrikse, N. H. et al. ${ }^{99 m}$ Tc-sestamibi is a substrate for P-glycoprotein and the multidrug resistance-associated protein. Br. J. Cancer 77, 353-358 (1998)

144. Chen, W. S. et al. Effects of MDR1 and MDR3 Pglycoproteins, MRP1, and BCRP/MXR/ABCP on the transport of (99m)Tc-tetrofosmin. Biochem. Pharmacol. 60 413-426 (2000).

145. Beketic-Oreskovic, L., Duran, G. E., Chen, G., Dumontet, C. \& Sikic, B. I. Decreased mutation rate for cellular resistance to doxorubicin and suppression of $M d r 1$ gene activation by to doxorubicin and suppression of Mdr1 gene activati 1593-1602 (1995).

\section{Cells exposed to doxorubicin in the presence of} PSC-833 develop resistance less frequently, supporting an argument for early intervention with PGP inhibitors.

146. Abolhoda, A. et al. Rapid activation of MDR1 gene expression in human metastatic sarcoma after in vivo exposure to doxorubicin. Clin. Cancer Res. 5, 3352-3356 (1999).

147. Lee, J. S. et al. Rhodamine efflux patterns predict P-glycoprotein substrates in the National Cancer Institute Drug Screen. Mol. Pharmacol. 46, 627-638 (1994).

148. Sorrentino, B. P. et al. Selection of drug-resistant bone marrow cells in vivo after retroviral transfer of human MDR Science 257, 99-103 (1992).

First use of MDR1 in a gene therapy setting, providing a means to increase dose intensity by protecting bone-marrow cells from chemotherapy toxicity.

149. Flasshove, M. et al. Ex vivo expansion and selection of human CD34+ peripheral bla bansion and selection of introduction of a mutated dihydrofolate reductase cDNA via retroviral gene transfer. Blood $\mathbf{8 5}, 566-574$ (1995).

150. Moscow, J. A. et al. Engraftment of MDR1 and NeoR genetransduced hematopoietic cells after breast cancer chemotherapy. Blood 94, 52-61 (1999).

151. Bunting, K. D., Galipeau, J., Topham, D., Benaim, E. \& Sorrentino, B. P. Transduction of murine bone marrow cells with an MDR1 vector enables ex vivo stem cell expansion, but these expanded grafts cause a myeloproliferative syndrome in transplanted mice. Blood 92, 2269-2279 (1998).
152. Dano, K. Active outward transport of daunomycin in resistant Ehrlich ascites tumor cells. Biochim. Biophys. Acta 323, 466-483 (1973).

153. Abraham, J. et al. A phase I study of the nove P-glycoprotein (PGP) antagonist, XR9576 in combination with vinorelbine. Proc. Am. Soc. Clin. Oncol. 20, 287 (2001).

154. Dantzig, A. H. et al. Reversal of P-glycoprotein-mediated multidrug resistance by a potent

cyclopropyldibenzosuberane modulator, LY335979. Cancer Res. 56, 4171-4179 (1996).

155. Starling, J. J. et al. Pharmacological characterization of LY335979: a potent cyclopropyldibenzosuberane modulator of P-glycoprotein. Adv. Enzyme Regul. 37 335-347 (1997)

156. Hyafil, F., Vergely, C., Du Vignaud, P. \& Grand-Perret, T. In vitro and in vivo reversal of multidrug resistance by GF120918, an acridonecarboxamide derivative. Cancer Res. 53, 4595-4602 (1993).

157. de Bruin, M., Miyake, K., Litman, T., Robey, R. \& Bates, S. E. Reversal of resistance by GF120918 in cell lines expressing the ABC half-transporter, MXR. Cancer Lett. 146, 117-126 (1999).

158. Lowe, S. W., Ruley, H. E., Jacks, T. \& Housman, D. E. p53-dependent apoptosis modulates the cytotoxicity of anticancer agents. Cell 74, 957-967 (1993).

159. Schneider, J. et al. Expression of LRP and MDR1 in locally advanced breast cancer preditcs axillary node invasion at the time of rescue mastectomy after induction chemotherapy. Breast Cancer Res. 3, 183-191 (2001).

160. Tolcher, A. W. et al. Phase I crossover study of paclitaxel with $r$-verapamil in patients with metastatic breast cancer. J. Clin. Oncol. 14, 1173-1184 (1996).

161. Mechetner, E. et al. Levels of multidrug resistance (MDR1) P-glycoprotein expression by human breast cancer correclate with in vitro resistance to taxol and doxorubicin. Clin. Cancer Res. 4, 389-398 (1998).

162. Izquierdo, M. A. et al. Drug resistance-associated marker LRP for prediction of response to chemotherapy and prognoses in advanced ovarian carcinoma. J. Nat/ Cancer Inst. 87, 1230-1237 (1995).

163. Schneider, J., Jimenez, E., Marenbach, K., Marx, D. \& Meden, $\mathrm{H}$. Co-expression of the MDR1 gene and HSP27 in human ovarian cancer. Anticancer Res. 18, 2967-2971 (1998).

164. Baekelandt, M. M., Holm, R., Nesland, J. M., Troupe, C. G. \& Kristensen, G. B. P-glycoprotein expression is a marker for chemotherapy resistance and prognosis in advanced ovarian cancer. Anticancer Res. 20, 1061-1067 (2000).

165. Fedeli, L. et al. Pharmacokinetics of vincristine in cancer patients treated with nifedipine. Cancer 64, 1805-1811 (1989)

\section{(2) Online links}

\section{DATABASES}

The following terms in this article are linked online to: CancerNet: http://cancernet.nci.nih.gov/

acute myelogenous leukaemia | adrenocortical cancer | breast tumours | chronic lymphocytic leukaemia | colon cancer | hepatocellular cancer | kidney cancer | non-small-cell lung cancers | oesophageal carcinoma | osteosarcomas | soft-tissue sarcomas

LocusLink: http://www.ncbi.nlm.nih.gov/LocusLink/ ABCA2 | ABCB1 | ABCG2 | BSEP | cytochrome P450 | Mdr1a Mdr1b | MDR3 | Mrp1 | MRP1 | Mrp2 | MRP2 | MRP3 | MRP6 | p53| SXR

\section{Medscape Druglnfo:}

http://promini.medscape.com/drugdb/search.asp amiodarone | cisplatin | cyclosporin A | daunorubicin | docetaxel doxorubicin | etoposide | 5-fluorouracil | methotrexate | mitoxantrone | nifedipine | paclitaxel | progesterone | quinidine | quinine | tamoxifen | verapamil | vinblastine | vincristine OMIM: http://www.ncbi.nlm.nih.gov/Omim/

Dubin-Johnson syndrome | progressive familial intrahepatic cholestasis type-3

\section{FURTHER INFORMATION}

Breast Cancer Drug Resistance Database:

http://www.lecb.ncifcrf.gov/breastDB/

The Center for Adaptation Genetics and Drug Resistance:

http://www.healthsci.tufts.edu/labs/Sblew/home.html

Access to this interactive links box is free online. 